ZOOLOGIA 31 (1): 81-87, February, 2014

http://dx.doi.org/10.1590/S1984-46702014000100009

\title{
Two new Brazilian species of the Neotropical sharpshooter genus Ruppeliana (Insecta: Hemiptera: Cicadellidae)
}

\author{
Rachel A. de Carvalho', Rodney R. Cavichioli², Luiz Gabriel N. Rodrigues ${ }^{1} \&$ Ana C. Gonçalves ${ }^{3}$ \\ 1 Departamento de Entomologia, Museu Nacional, Universidade Federal do Rio de Janeiro. Quinta da Boa Vista, \\ São Cristóvão, 20940-040 Rio de Janeiro, RJ, Brazil. E-mail: rachel_alexandre@yahoo.com.br \\ ${ }^{2}$ Departamento de Zoologia, Universidade Federal do Paraná. Caixa Postal 19020, 81531-980 Curitiba, PR, Brazil. \\ ${ }^{3}$ Illinois Natural History Survey, Prairie Research Institute, University of Illinois at Urbana-Champaign. 1816 S Oak Street, \\ Champaign, IL 61820, USA.
}

\begin{abstract}
Two new Ruppeliana Young, 1977 species are described and illustrated based on specimens from the states of Espírito Santo and Minas Gerais, Brazil. The new species are easily distinguished from other Ruppeliana Young, 1977 by their color pattern. Ruppeliana caelimaculata sp. nov. has red to dark red forewings with whitish-blue transverse maculae, and $R$. flavivirescens sp. nov. has brownish-red forewings with greenish-yellow longitudinal stripes. The female genitalia are for the first time described and illustrated in detail for species of the genus.
\end{abstract}

KEY WORDS. Auchenorrhyncha; leafhopper; Cicadellinae; Membracoidea; taxonomy.

Ruppeliana Young, 1977 includes nine sharpshooter species: $R$. coronota (Signoret, 1853), R. coronulifera (Stål, 1862), $R$. episcopalis (Signoret, 1852), R. fulva (Taschenberg, 1884), $R$. glaucomaculata (Germar, 1821), R. nigripes (Signoret, 1853), $R$. signiceps (Stål, 1862; type-species), R. taschenbergi (Berg, 1889), and $R$. tatia Young, 1977. The genus is recorded from southeastern and southern Brazil and northern Argentina (Young 1977, Zanol \& de Menezes 1982, Oman et al. 1990, McKamey 2007). According to Young (1977), the male and female genitalia of species of Ruppeliana and Pawiloma Young, 1977 are similar, but Ruppeliana males can be promptly differentiated by the elongate basal processes of the aedeagus.

In this paper two new Ruppeliana species are described and illustrated based on the male and female specimens from the Brazilian states of Espírito Santo and Minas Gerais. The female genitalia are for the first time described and illustrated in detail for species of the genus.

\section{MATERIAL AND METHODS}

The genital structures of males and females were prepared according to the techniques described by OMAN (1949) and Mejdalani (1998), respectively. The ovipositor valvulae were mounted on temporary slides with glycerin. Dissected parts were stored in small vials containing glycerin. The morphological terminology adopted herein follows mainly Young (1968, 1977), except for the head (Hamilton 1981, Mejdalani 1998) and the female genitalia (Hill 1970). In quotations of label data, a reversed virgule $(\backslash)$ separates lines on a label and a semicolon separates information on different labels. The specimens studied belong to the following collections: Coleção Entomológica Padre. Jesus Santiago Moure, Departamento de Zoologia, Universidade Federal do Paraná, Curitiba (DZUP), Coleção Entomológica Professor José Alfredo P. Dutra, Departamento de Zoologia, Instituto de Biologia, Universidade Federal do Rio de Janeiro, Rio de Janeiro (DZRJ), Departamento de Entomologia, Museu Nacional, Universidade Federal do Rio de Janeiro, Rio de Janeiro (MNRJ).

\section{TAXONOMY}

\section{Ruppeliana caelimaculata Carvalho,} Cavichioli, Rodrigues \& Gonçalves, sp. nov.

Figs 1-15

Description. Length. Male holotype: $9.9 \mathrm{~mm}$; male paratypes: 9.0-9.7 $\mathrm{mm}$; female paratype: $10.2 \mathrm{~mm}$ (female with apex of wings damaged).

External morphology. Head (Figs 1 and 2), in dorsal view, with median length of crown almost $1 / 2$ of interocular width and approximately $1 / 3$ of transocular width; ocelli located slightly behind imaginary line between anterior eye angles, each ocellus closer to adjacent anterior eye angle than median line of crown; antennal ledges, in dorsal view, slightly protuberant. Frons with central area rugose; epistomal suture obsolete medially. Pronotum (Figs 1 and 2) with lateral margins slightly convergent anteriorly; dorsopleural carinae complete, approximately rectilinear, declivent anteriorly; posterior margin with shallow reentrance medially; disk of pronotum with shallow median concavity on anterior portion. Forewings (Fig. 1) with mem- 


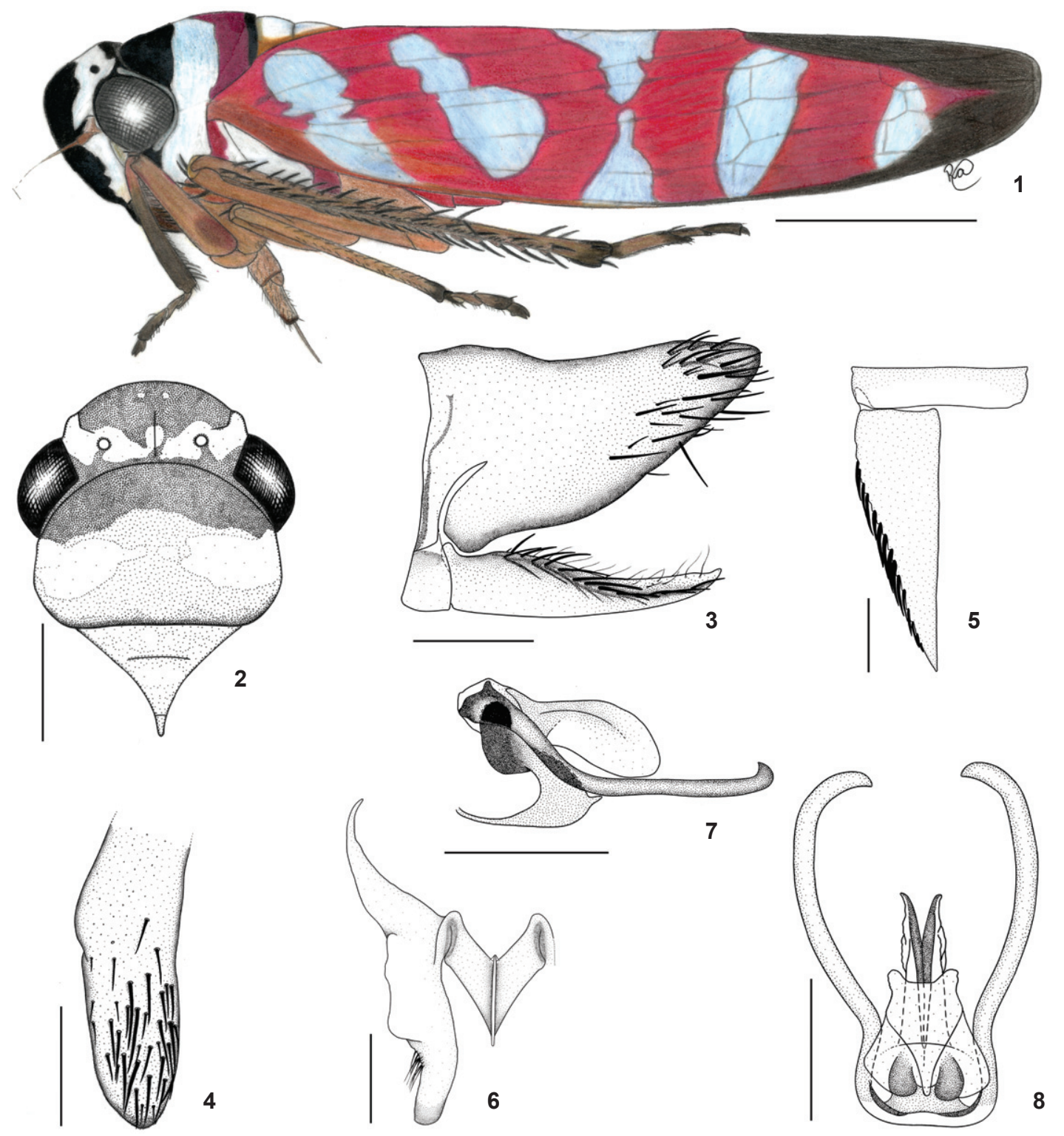

Figures 1-8. Ruppeliana caelimaculata sp. nov., male holotype: (1) body in lateral view; (2) anterior dorsum; (3) pygofer, valve and subgenital plate, lateral view; (4) pygofer apex, ventral view; (5) valve and subgenital plate, ventral view; (6) connective and style, dorsal view; $(7,8)$ aedeagus and its processes in lateral (7) and ventral (8) view. Scale bars: $1=2.0 \mathrm{~mm} ; 2=1.0 \mathrm{~mm} ; 3,4,5,7,8=0.5 \mathrm{~mm} ; 6=0.2 \mathrm{~mm}$.

brane including all apical cells; veins not elevated but distinct; with bases of two inner anteapical cells approximately aligned with claval apex and base of outer anteapical cell more proximal than claval apex. Remaining morphological characteristics of head and thorax as in the generic description of Young (1977).

Color. Head (Figs 1 and 2) black. Crown with transverse band reaching antennal ledges (may be interrupted near coronal suture) and with pair of very small maculae at apex, whitish-blue. Face with pair of broad lateral stripes, connected to the band of crown and extending to upper portion of clypeus and with pair of small elongate maculae on upper median portion of frons (absent in holotype), whitish-blue. Clypeus mostly brown. Pronotum (Figs 1 and 2) red to dark red; disk with black arc anteriorly, with lateral pair of whitish-blue maculae extending onto lateral lobes, and with narrow black line bordering posterior margin. Mesonotum brown, mostly covered with irregular whitish-blue marks. Ground color of forewings (Fig. 1) red to dark red with the following whitish-blue marks: two 

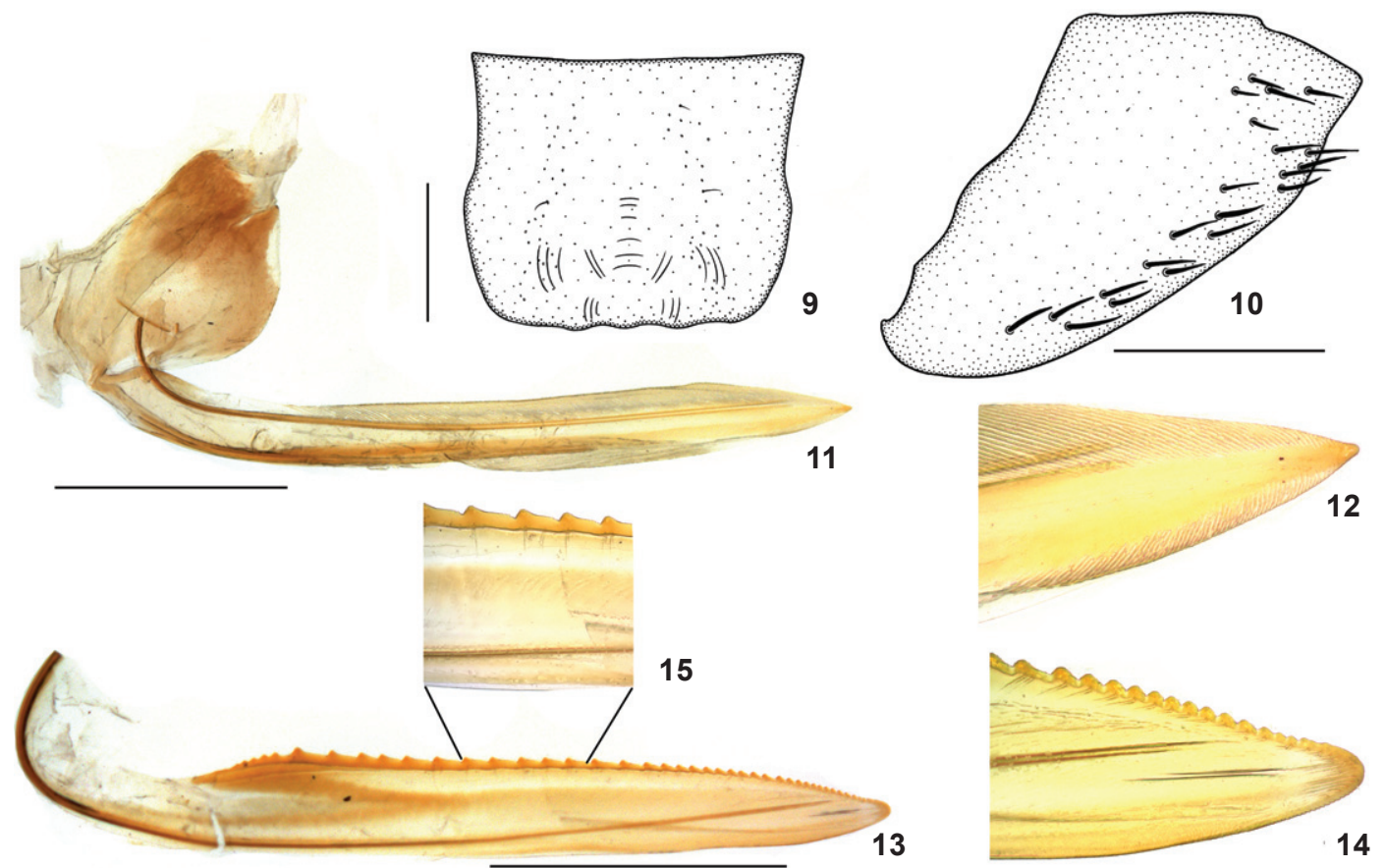

Figures 9-15. Ruppeliana caelimaculata sp. nov., female paratype: (9) sternite VII, ventral view; (10) pygofer, lateral view; (11) first valvula and valvifer, lateral view; (12) apex of first valvula in higher magnification; (13) second valvula, lateral view; (14) apex of second valvula in higher magnification; (15) teeth of second valvula in detail. Scale bars: $9=0.5 \mathrm{~mm} ; 10,11,13=1.0 \mathrm{~mm}$.

oblique stripes basally, one extending from costal to inner margin near base of mesonotum and another extending from outer discal cell to inner claval cell (in some paratypes it may be interrupted forming two contiguous oblique maculae, one on corium and another on clavus); with two aligned triangular maculae near midlength almost reaching each other, one transcomissural and another at costal margin (in some paratypes the costal one is absent); and with two transverse maculae on corium, a broader one at base of anteapical cells and another just before membrane; membrane smoky black. Legs mostly brown with apex of tibiae and tarsi dark brown...Male genitalia. Pygofer (Figs 3 and 4) strongly produced posteriorly, posterior margin narrowly rounded; with numerous macrosetae on apical half; ventral margin (Fig. 4), in ventral view, with broadly rounded projection on apical third; without processes. Valve (Fig. 5), in ventral view, narrow with posterior margin slightly concave medially. Subgenital plates (Figs 3 and 5) slender and triangular, gradually tapering apically, almost as long as pygofer, with uniseriate macrosetae along outer margin and with few microsetae on dorsal margin. Styles (Fig. 6) extending posteriorly beyond apex of connective, with small setae preapically, with preapical lobe, apical portion digitiform. Connective (Fig. 6) short, V-shaped, stalk very short, narrow, with high median keel. Aedeagus (Figs 7 and 8), in lateral view, with shaft slightly expanded apically and directed posteroventrally; in dorsal view, with deep dorsal split; aedeagal atrium well developed, forming ventral sheathlike portion that is linked to connective, and bearing two pairs of processes: basal processes very long, slender and robust, almost twice longer than aedeagal shaft, with apex directed inwardly; distal processes located dorsoapically, short and spiniform. Paraphyses absent.

Female genitalia. Abdominal sternite VII (Fig. 9) weakly produced posteriorly; posterior margin approximately rectilinear with few small emarginations; ventral surface with few weak transverse striae medially, without setae. Internal sternite VIII completely membranous. Pygofer (Fig. 10) strongly produced posteriorly, posterior margin subacute, macrosetae on apical third and extending anteriorly along ventral margin. First valvifers (Fig. 11) broad, expanded posteriorly, with rounded lobe on posteroventral margin. First valvulae (Figs 11 and 12) long, slightly broadened on median third and slightly narrowed toward acute apex (Fig. 12); with sculptured sclerotized area strigate on almost all dorsal margin and on ventral margin near apex. Second valvulae (Figs 13-15) long, slender, slightly expanded beyond basal curvature and gradually narrowed toward apex; bearing about 42 teeth, first ones small and triangular, followed by some subrectangular and larger ones (Fig. 15), becoming progressively smaller and triangular toward narrowly rounded apex (Fig. 14); with few denticles on posterior portion of almost all teeth (except apical ones) and on ventral margin of apical portion; ventral margin approximately rectilinear, without preapical prominence. Genitalia without additional sclerites or processes. 
Type material. Holotype: male, BrAzIL, Espírito Santo: "BR/ ES, Santa Teresa \Parque Municipal \São Lourenço $\backslash 22-23 / V I /$ 2007\A. C. GONÇALVES \&\R. A. CARVALHO col." (MNRJ). Paratypes: one male, same data as holotype (MNRJ); one male and one female, "BR/ES/St ${ }^{\mathrm{a}}$. [Santa] Teresa $\backslash$ Parq. [Parque] Muni.[Municipal] São \Lourenço $03 \backslash I I \backslash 2009 \backslash$ R. A. Carvalho col." (MNRJ); one female, "BR/ES, Santa Teresa \Est.[Estação] Bio.[Biológica] Santa Lúcia $\backslash 24-28 / V I / 2009 \backslash R$. CARVALHO, A. CARPI, L. \NOGUEIRA \& M. LOPES Col." (DZUP); one male, "BR/ES, Santa Teresa \Est. Bio. Santa Lúcia \12/XI/2009\R. Carvalho \& M. M. Lopes Col."(DZRJ); one male, same data as preceding except "07-11/II/2010" (MNRJ); one male, same data as preceding except "16/X/2009 \M.M. Lopes Col" (DZUP); one male, "BR/ES, Santa Teresa $\backslash$ Res.[Reserva] Bio.[Biológica] Augusto Ruschi \19-23/VIII/2009 \R. Carvalho \& M. Lopes Col” (MNRJ).

Etymology. The specific epithet, caelimaculata, is of Latin derivation and refers to the whitish-blue maculae on the forewings.

\section{Ruppeliana flavivirescens Carvalho, Cavichioli, Rodrigues \& Gonçalves, sp. nov.}

\section{Figs 16-30}

Description. Length. Male holotype: $10.7 \mathrm{~mm}$; male paratypes: 10.1-10.8 mm; female paratypes: $11.1-11.6 \mathrm{~mm}$.

External morphology. Head (Figs 16 and 17), in dorsal view, moderately produced anteriorly; median length of crown almost $1 / 2$ interocular width and approximately $1 / 3$ transocular width; ocelli located slightly behind imaginary line between anterior eye angles, each approximately equidistant from adjacent anterior eye angle and median line of crown; with concavity between each ocellus and adjacent eye; without sculpturing or setae. Frons with central area granular; epistomal suture obsolete medially. Clypeus slightly pubescent at apex. Pronotum (Figs 16 and 17) with lateral margins slightly convergent anteriorly; dorsopleural carinae complete, rectilinear, declivous anteriorly; disk with median transverse depression next to anterior margin; posterior margin with slight reentrance medially. Forewings (Fig. 16) with membrane restricted to apex of apical cells; veins more visible apically; base of outermost anteapical cell more proximal than claval apex. Remaining morphological characteristics of head and thorax as in the generic description of Young (1977).

Color. Head (Figs 16 and 17), thorax and legs brownishyellow. Some irregular markings on crown, three longitudinal lines on frons and apex of clypeus, brown. Pronotum (Figs 16 and 17) with anterior depressed region, transversal band on posterior third, pair of maculae at posterior margin and thin line along this margin, brown to dark brown (other small marks may be present). Mesonotum with small mark posteriorly and two pairs of spots, one at lateral angles and another, small and rounded, before transverse sulcus, dark brown. Forewings (Fig. 16) brownish-red with about four irregular greenish-yellow lon- gitudinal stripes, two on clavus and two on discal cells extending onto anteapical cells; membrane translucent smoky black.

Male genitalia. Pygofer (Figs 18 and 19), in lateral view, moderately produced posteriorly, apical margin narrowly rounded; macrosetae concentrated on apical half, ventrobasal portion and posterior margin bearing small setae; ventral margin, in ventral view, with rounded projection near apical third; without processes. Valve (Fig. 20), in ventral view, narrow with posterior margin slightly concave. Subgenital plates (Fig. 20), in ventral view, elongate and triangular, gradually tapering toward apex, with uniseriate macrosetae and several elongate microsetae along outer margin; in lateral view, extending posteriorly almost as far as pygofer apex. Styles (Fig. 21), in dorsal view, extending posteriorly beyond apex of connective; with few preapical setae, without preapical lobe; apex blunt. Connective (Fig. 21), in dorsal view, very short, V-shaped, with high median keel. Aedeagus (Figs 22 and 23), in lateral view, with shaft broadly expanded apically and slightly directed posteroventrally; in dorsal view, with deep dorsal split; aedeagal atrium well developed, forming a ventral sheathlike portion that is linked to connective, and bearing two pairs of processes: first pair arising basally, slender, short, not exceeding aedeagal apex; second pair positioned dorsoapically, short and stout, with acute apex. Paraphyses absent.

Female genitalia. Abdominal sternite VII (Fig. 24) produced posteriorly; posterior margin approximately rectilinear with small concavity medially; posterolateral corners slightly produced; ventral surface with few weak longitudinal and transverse striae, without setae. Internal sternite VIII completely membranous. Pygofer (Figs 24 and 25) strongly produced posteriorly, posterior margin subacute, macrosetae mostly on apical third and extending anteriorly along ventral margin. First valvifers (Fig. 26) rounded. First valvulae (Figs 26 and 27) long, slightly expanded at median third and narrowed toward acute apex (Fig. 27); with sculptured sclerotized area strigate on almost all dorsal margin and on ventral margin near apex. Second valvulae (Figs 28-30) long, slender, slightly expanded beyond basal curvature, gradually narrowed toward apex; ventral margin approximately rectilinear; without preapical prominence; apex (Fig. 29) curved dorsally and narrowly rounded; bearing about 44 teeth, basally with a sequence of small and irregular teeth, followed by few triangular and some large and somewhat rectangular ones (Fig. 30), becoming progressively smaller and triangular toward apex; denticles on all teeth, and on dorsal and ventral margin of apical portion. Genitalia without additional sclerites or processes.

Type material. Holotype: male, BrazIL, Minas Gerais: "Brasil, MG, Itamonte $\backslash 2100-1700 \mathrm{~m}$ altitude $\backslash 21-23 . X I .2008 \backslash \mathrm{CARVALHO}$, R.; EVANGELISTA, $\backslash \mathrm{O} \&$ TAKIYA, D. Cols." (MNRJ); one male and one female, same data as holotype (MNRJ); two males and one female, same data as holotype except "20.XI.2008" (DZUP); one female, same data as holotype except "24-29.XI.2010"(MNRJ); four males and one female, "BRASIL: MG, Itamonte $\backslash 2400-1700 \mathrm{~m}$ asI \01-03.XI.2007\D. M. Takiya leg." (DZRJ). 


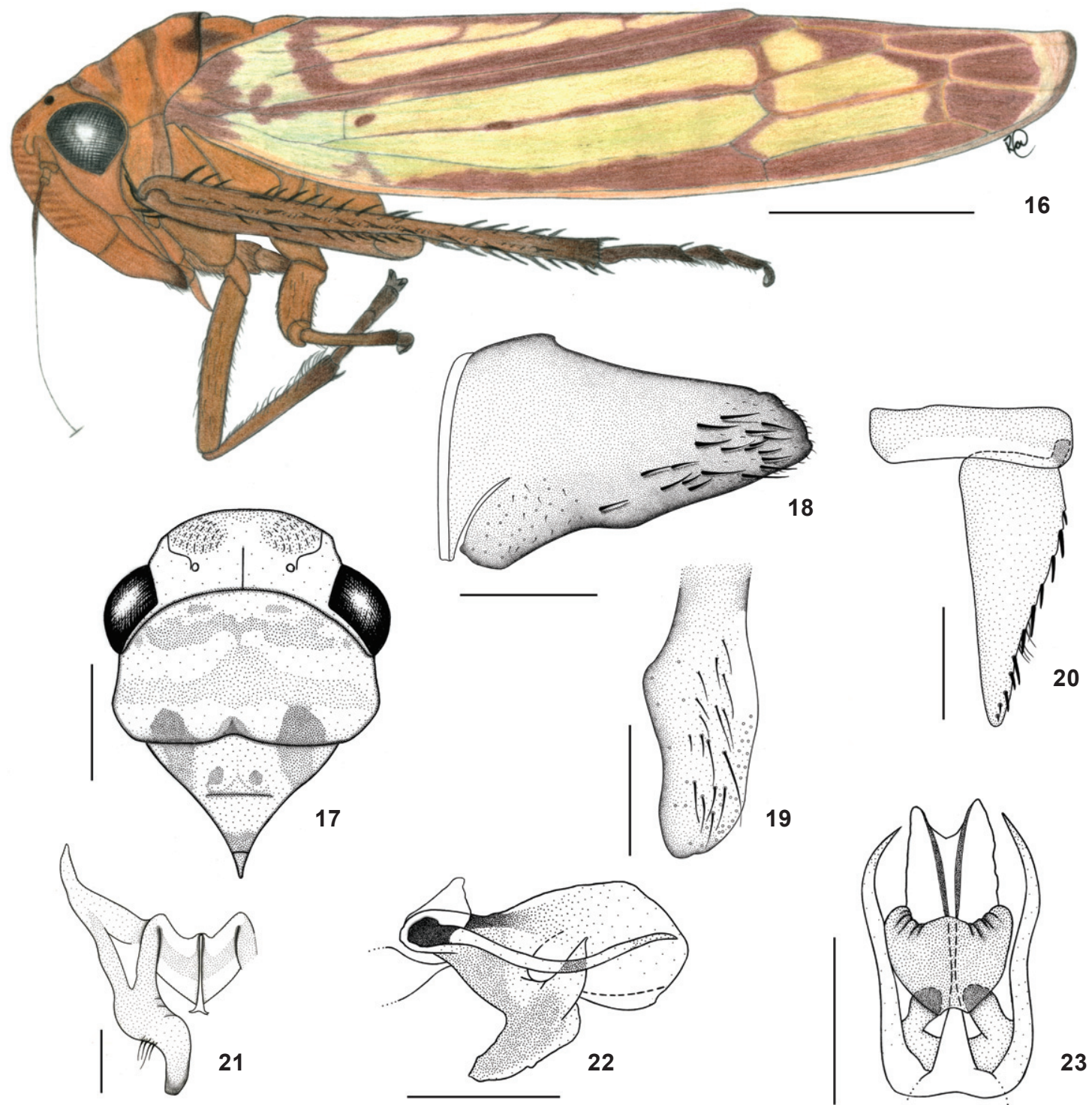

Figures 16-23. Ruppeliana flavivirescens sp. nov., male holotype: (16) body in lateral view; (17) anterior dorsum; (18) pygofer, lateral view; (19) pygofer apex, ventral view; (20) valve and subgenital plate, ventral view; (21) connective and style, dorsal view; (22, 23) aedeagus and its processes in lateral (22) and ventral (23) view. Scale bars: $16=2.0 \mathrm{~mm} ; 17=1.0 \mathrm{~mm} ; 18,19,20,22,23=0.5 \mathrm{~mm} ; 21=0.2 \mathrm{~mm}$.

Etymology. The specific epithet, flavivirescens, is of Latin derivation and refers to the greenish-yellow maculae on the forewings.

\section{DISCUSSION}

The two new species are promptly assigned to Ruppeliana based on characteristics of the male genitalia, mainly the aedeagus and its processes. Species within the genus can be recognized by the combination of the following features: 1 ) head well produced and broadly rounded, 2) male pygofer strongly produced posteriorly, 3) subgenital plates slender and triangular, 4) shaft of the aedeagus arched and usually expanded apically (except in $R$. tatia), and 5) aedeagal atrium well developed, forming a sheathlike portion that is linked to the connective, and bearing two pairs of processes, one basal and another apical.

Ruppeliana caelimaculata sp. nov., as well as $R$. flavivirescens sp. nov., can be easily distinguished from other species of the genus by the color pattern of the dorsum, mainly the forewings. 


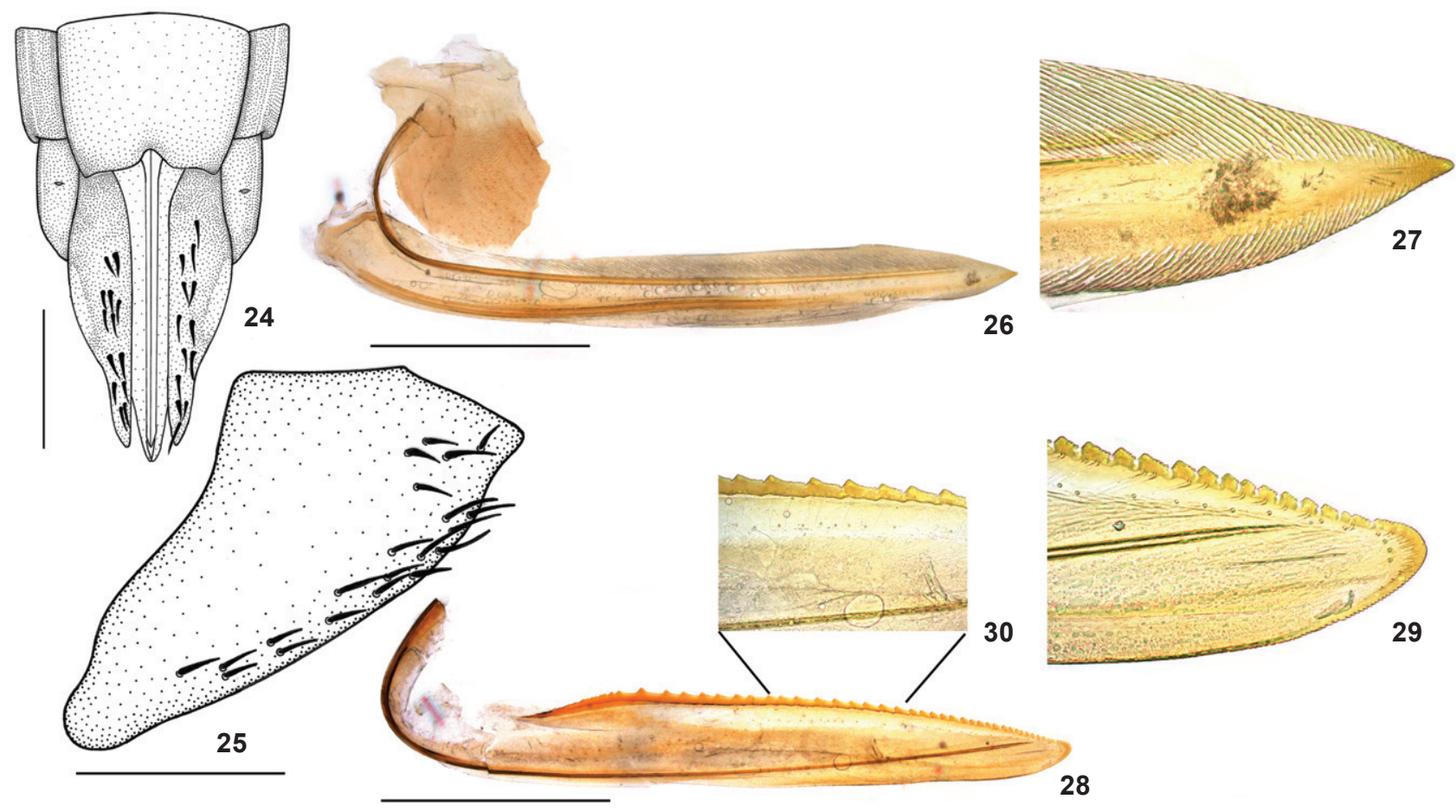

Figures 24-30. Ruppeliana flavivirescens sp. nov., female paratype: (24) apical portion of abdomen, ventral view; (25) pygofer, lateral view; (26) first valvula and valvifer, lateral view; (27) apex of first valvula in higher magnification; (28) second valvula, lateral view; (29) apex of second valvula in higher magnification; (30) teeth of second valvula in detail. Scale bars $=1.0 \mathrm{~mm}$.

The first species has red to dark red forewings (Fig. 2) with whitish-blue marks: two oblique stripes basally followed by two triangular and two transverse maculae. This pattern is not observed in any other species of the genus. Ruppeliana episcopalis and R. glaucomaculata have some bluish marks on the forewings but the pattern is very different from $R$. caelimaculata. The pattern of marks on the forewings of $R$. flavivirescens and $R$. nigripes are similar (with about four longitudinal irregular stripes), but the background color and stripes are very different, brownishred with greenish-yellow stripes in the new species (Fig. 16), and red to dark red with reddish-pink to pale pink stripes in $R$. nigripes.

In the male genitalia, the basal atrial processes of $R$. caelimaculata are very long, almost twice as long as the aedeagal shaft. A similar condition is observed in the illustration of the aedeagus of $R$. coronata provided by Young (1977: fig. 610 f-g). However, in the latter the styles extend posteriorly far beyond the apex of the connective, a feature not observed in the new species. Ruppeliana flavivirescens presents the basal atrial processes very short, not exceeding the aedeagal apex, a condition somewhat similar to that of R. glaucomaculata (Young 1977: fig. $614 \mathrm{f})$, but in the last species, the processes slightly exceed the apex of the aedeagus and are placed above the aedeagal shaft.

\section{ACKNOWLEDGMENTS}

We are thank D. Takiya (DZRJ) for the loan of specimens and G. Mejdalani (MNRJ) for the critical reading of the manuscript. The field work of RAC in Santa Teresa (ES) was kindly arranged by Rose L. Kollmann (Museu de Biologia Mello Leitão, Santa Teresa) and Eduardo Barros (MNRJ). Fellowships from Coordenação de Aperfeiçoamento de Pessoal de Nível Superior (CAPES) and Fundação de Amparo à Pesquisa do Estado do Rio de Janeiro (FAPERJ; proc. E-26/103.372/2012) to RAC and from Conselho Nacional de Desenvolvimento Científico e Tecnológico (CNPq) to RRC (Proc. 303127/2010-7 and Protax Proc. 561298/ 2010-6), LGNR and ACG are greatly acknowledged.

\section{LITERATURE CITED}

Hamiton, K.G.A. 1981. Morphology and evolution of the rhynchotan head (Insecta: Hemiptera, Homoptera). Canadian Entomologist 113: 953-974.

HILL, B.G. 1970. Comparative morphological study of selected higher categories of leafhoppers (Homoptera: Cicadellidae). Ann Arbor, University Microfilms, XI+187p.

McKamey, S.H. 2007. Taxonomic catalogue of the leafhoppers (Membracoidea). Part 1. Cicadellinae. Memoirs of the Ame- 
rican Entomological Institute 78: 1-394.

Mejdalani, G. 1998. Morfologia externa dos Cicadellinae (Homoptera, Cicadellidae): comparação entre Versigonalia_ruficauda (Walker) (Cicadellini) e Tretogonia_cribrata Melichar (Proconiini), com notas sobre outras espécies e análise da terminologia. Revista Brasileira de Zoologia 15 (2): 451-544. doi: 10.1590/S0101-81751998000200015.

Oman, P.W. 1949. The Nearctic leafhoppers (Homoptera: Cicadellidae). A generic classification and check list. Memoirs of the Entomological Society of Washington 3: 1-253.

OMAN, P.W.; W.J. KNight \& M.W. NieLSON. 1990. Leafhoppers (Cicadellidae): a bibliography, generic check-list and index to the World literature 1956-1985. Wallingford, $C A B$ International Institute of Entomology, 368p.

YounG, D.A. 1968. Taxonomic study of the Cicadellinae (Homoptera: Cicadellidae). Part 1. Proconiini. Bulletin of the United States National Museum 261: 1-287.

Young, D.A. 1977. Taxonomic study of the Cicadellinae (Homoptera: Cicadellidae). Part 2. New World Cicadellini and the genus Cicadella. Bulletin of North Carolina Agricultural Experiment Station 239: VI+1135p.

Zanol, K.M.R. \& M. DE Menezes. 1982. Lista preliminar dos cicadelídeos (Homoptera, Cicadellidae) do Brasil. Iheringia, Série Zoologia, 61: 9-65.

Submitted: 01.VIII.2013; Accepted: 02.XI.2013.

Editorial responsibility: Gabriel L.F. Mejdalani 